Effects of magnesi um on the product $i$ on of ext racel I ul ar mat $r$ i $x$ met al l opr ot ei nases i $n$ cultured $r$ at vascul ar smooth miscle cel is

\begin{tabular}{|l|l|}
\hline 著者 & $\begin{array}{l}\text { YUE Hong, LEE J ong- Dae, SH M ZU H r onasa, UZUI } \\
\text { H r oyasu, M TSUKE Yasuhi ko, UEDA Takanor i }\end{array}$ \\
\hline $\begin{array}{l}\text { j our nal or } \\
\text { publ i cat i on t i t l e }\end{array}$ & At her oscl er osi s \\
\hline vol une & 166 \\
\hline page r ange & $271-277$ \\
\hline year & 2003 \\
\hline URL & $\mathrm{ht} \mathrm{t} \mathrm{p:} \mathrm{//hdl} \mathrm{.} \mathrm{handl} \mathrm{e.} \mathrm{net} \mathrm{/10098/2958}$ \\
\hline
\end{tabular}




\title{
Effects of magnesium on the production of extracellular matrix metalloproteinases in cultured rat vascular smooth muscle cells
}

\author{
Hong Yue, Jong-Dae Lee*, Hiromasa Shimizu, Hiroyasu Uzui, Yasuhiko Mitsuke, \\ Takanori Ueda
}

First Department of Internal Medicine, Fukui Medical University, 23-3 Shimoaizuki, Matsuoka-Cho, Fukui 910-1193, Japan

Received 29 April 2002; received in revised form 18 October 2002; accepted 25 October 2002

\begin{abstract}
The precise correlation between magnesium and cardiovascular disease remains to be established. Matrix metalloproteinases (MMPs) are expressed in coronary arterial atherosclerotic lesions. MMP production in vascular smooth muscle cells (VSMCs) is stimulated by growth factors such as platelet-derived growth factor (PDGF). To assess the association between magnesium and MMPs, we examined the effects of different extracellular magnesium concentrations ( $0-3.0 \mathrm{mmol} / 1)$ on MMPs production in cultured rat VSMCs under basal and PDGF-stimulated conditions using gelatin zymography and western blotting. As magnesium is called a natural calcium antagonist, we further compared the effects of magnesium with some calcium antagonists. Magnesium reduced MMP-2 production dose-dependently at basal and PDGF-stimulated conditions in VSMCs. However, neither verapamil nor nifedipine influenced MMP-2 production under any conditions examined. The effect of magnesium on the production of MMP2 was inhibited by two tyrosine kinase inhibitors-genistein and herbimycin A. The results of this study indicate that extracellularly added magnesium decreased MMPs secretion, which appears to be associated with protein tyrosine kinase.
\end{abstract}

(C) 2002 Elsevier Science Ireland Ltd. All rights reserved.

Keywords: Magnesium; Matrix metalloproteinase; Atherosclerosis; Smooth muscle cell

\section{Introduction}

Magnesium has been implicated in the negative correlation between cardiovascular disease and hardness of drinking water [1]. Dietary deficiency of magnesium augments atherogenesis markedly in experimental animals fed a high cholesterol diet, while oral supplementation of magnesium to similar animals lowers serum lipids and attenuates the atherosclerotic process [2]. The magnesium status of men with variant angina has been proven to be closely related to disease activity [3]. However, Liao et al. indicated that the association of low serum and dietary magnesium with the incidence of coronary heart disease should not yet to be causal, because results of this prospective study differed between men and women [4]. Thus, the precise role of low serum magnesium in the progression of cardiovascular disease remains to be established.

The extracellular matrix metalloproteinases (MMPs) are a family of distinct proteases with differing specificities of cleavaging toward various extracellular matrix components [5]. It has been reported that the processes of migration and proliferation of vascular smooth muscle cells (VSMCs) that contribute to the morphogenesis of atherosclerotic plaques require the extracellular matrix remodeling caused by MMPs [6]. The production of MMPs in VSMCs is known to be regulated by a number of cytokines and growth factors such as platelet-derived growth factor (PDGF) secreted by platelets and vascular cells [7-9]. Among the MMPs, MMP-2 has the widest distribution, and plays an important role in the turnover of basement membrane type IV collagen and in controlling cell proliferation [10]. The proliferation and migration of VSMCs was demonstrated to be closely related to the stimulation of MMP-2 production [9]. An increased expression of MMP-2 has been revealed in atherosclerotic plaques 
[11]. All these studies suggested that MMP-2 plays an important role in the formation and progression of atherosclerotic lesion.

Numerous signal transduction pathways utilize ionized calcium as a second messenger. A calciumregulated pathway has been shown to regulate MMP-2 production [12]. However, the effect of magnesium, which is a natural calcium antagonist [13], on MMPs in cultured VSMCs has not been studied up to now to our knowledge. The aim of this study is to test whether extracellularly added magnesium alters MMPs secretion. We investigated the effects of magnesium on production of MMP-2 at the basal and in PDGF stimulated conditions in VSMCs and further compared these effects with those of calcium antagonists-verapamil and nifedipine.

\section{Methods}

\subsection{Materials}

The chemicals used in this study were obtained from the following sources: Dulbecco's modified Eagle's medium (DMEM) without magnesium was obtained from GIBCO (Grand Island, NY), PDGF-BB was purchased from Biomedical Technologies (Stoughton, MA). Methyl- $\left[{ }^{3} \mathrm{H}\right]$ thymidine was obtained from Daiichi Radioisotopes (Tokyo, Japan), nifedipine was kindly supplied by Bayer Japan (Osaka, Japan). Anti-MMP-2 antibody was obtained from Fuji Chemical Industries (Toyama, Japan). Genistein and herbimycin A were purchased from Wako (Osaka, Japan). All other chemicals were of reagent grade or were of the highest grade commercially available.

\subsection{Preparation of smooth muscle cells}

VSMC strains were established from rat thoracic aorta (8-week-old male Sprague-Dawley rats) by the modified explant method as described previously [9]. Cultures were maintained in DMEM supplemented with $10 \%$ fetal calf serum. At confluence, cells displayed a 'hill and valley' growth pattern and abundant myofilaments in their cytoplasm. They were identified as VSMCs by immunocytochemistry using HHF35, a monoclonal antibody that recognizes muscle-specific actin [14]. All VSMC cultures used in this study were between passages 4 and 7 . At the subconfluent stage, the culture medium was replaced with serum-free medium and then cells were exposed to various treatments.

\subsection{Preparation of culture medium}

Magnesium sulfate $\left(\mathrm{MgSO}_{4}\right)$ or magnesium chloride was added to DMEM without magnesium to the final magnesium concentrations of $0-3.0 \mathrm{mmol} / 1$ before use. The level of $0-0.5 \mathrm{mmol} / \mathrm{l}$ magnesium corresponds to the lowest physiological level of this ion that can be measured in human serum, $1.0 \mathrm{mmol} / 1$ to the physiological level, and $3.0 \mathrm{mmol} / \mathrm{l}$ to the highest level reached by therapeutic supplementation of magnesium in patients with arrhythmia or preeclampsia. Cells were treated with calcium antagonists of final concentrations between $10^{-8} \mathrm{~mol} / 1$ and $10^{-6} \mathrm{~mol} / 1$ in the presence or absence of PDGF in $1.0 \mathrm{mmol} / 1$ magnesium DMEM. All treatments were sustained in the upper media for 24 h.

\subsection{DNA synthesis}

VSMCs were plated in 6-well plates $\left(1 \times 10^{5}\right.$ cells per well), incubated at $37{ }^{\circ} \mathrm{C}$ in a humidified atmosphere of $95 \%$ air $-5 \% \mathrm{CO}_{2}$, and maintained in DMEM with $10 \%$ fetal calf serum until subconfluent $(50-70 \%$ confluent). After incubation with PDGF $(10 \mathrm{ng} / \mathrm{ml})$, verapamil $\left(10^{-8}-10^{-6} \mathrm{~mol} / \mathrm{l}\right)$, nifedipine $\left(10^{-8}-10^{-6} \mathrm{~mol} / \mathrm{l}\right)$, magnesium $(0-3.0 \mathrm{mmol} / \mathrm{l})$ or various combinations, $\left[{ }^{3} \mathrm{H}\right]$ thymidine $(1 \mu \mathrm{Ci} / \mathrm{ml})$ was added followed by incubation for $24 \mathrm{~h}$. DNA synthesis was determined by measuring the trichloroacetic acid-insoluble radioactivity [15]. After incubation, the trypsinized VSMCs were suspended in ice-cold $10 \%$ trichloroacetic acid. The lysates were placed on ice for $10 \mathrm{~min}$, followed by a passage through paper filters (Whatman, Maidstone, UK). The filters were washed with cold $10 \%$ trichloroacetic acid and dried. Incorporated $\left[{ }^{3} \mathrm{H}\right]$ thymidine was measured in an Aloka LSC-3500 scintillation counter (Aloka, Tokyo, Japan).

\subsection{Analysis of gelatinase production}

After various treatments for $24 \mathrm{~h}$, medium samples were harvested, centrifuged at $2000 \times g$ for $10 \mathrm{~min}$ and normalized for cell protein content using Bio-Rad assay [9]. The samples were applied without reduction to a $7.5 \%$ polyacrylamide slab gel impregnated with $1 \mathrm{mg} / \mathrm{ml}$ gelatin [16]. After electrophoresis, the gel was washed at room temperature for $30 \mathrm{~min}$ in washing buffer $(50$ $\mathrm{mmol} / \mathrm{l}$ Tris-Cl, pH 7.5, $15 \mathrm{mmol} / 1 \mathrm{CaCl}_{2}, 1 \mu \mathrm{mol} / \mathrm{l}$ $\mathrm{ZnCl}_{2}$, and $2.5 \%$ Triton $\mathrm{X}-100$ ), then incubated overnight at $37{ }^{\circ} \mathrm{C}$ with shaking in the same buffer but containing $1 \%$ rather than $2.5 \%$ Triton $\mathrm{X}-100$. The gel was stained with a solution of $0.1 \%$ Coomassie brilliant blue R-250. Clear zones against the blue background indicated the presence of gelatinase. To quantify the amount of gelatinase production, the stained zymograms were scanned on a densitograph (ATTO, Tokyo, Japan). 


\subsection{Western blotting analysis}

After various treatments for $24 \mathrm{~h}$, medium samples were harvested with the protease inhibitors phenylmethane sulfonyl fluoride $(0.1 \mathrm{mmol} / \mathrm{l})$ and leupeptin $(10 \mu \mathrm{g} / \mathrm{ml})$ from cells, centrifuged at $2000 \times g$ for $10 \mathrm{~min}$ and separated by electrophoresis on $7.5 \%$ sodium dodecyl sulfate polyacrylamide gels followed by transfer onto polyvinylidene difluoride membranes (Immobilon $\mathrm{P}$, Millipore, $0.22 \mu \mathrm{m}$ pore size). The membranes were blocked in $5 \%$ skim milk in phosphate-buffered saline containing $0.1 \%$ Tween 20 at room temperature for $1 \mathrm{~h}$, and probed with anti-MMP-2 monoclonal antibody overnight. After washing three times with phosphatebuffered saline containing $0.1 \%$ Tween 20 , the membranes were incubated with secondary antibody conjugated with horseradish peroxidase for $1 \mathrm{~h}$ as described previously [17]. Finally, the blots were washed and scanned on a densitograph.

\subsection{Statistical analysis}

Results were presented as percentages of the control and represent the mean \pm standard errors (S.E.) for four separate experiments performed in duplicate. Differences among all data were analyzed for statistical significance by one-way analysis of variance (ANOVA) followed by unpaired Student's $t$-test. Differences of $P<0.05$ were considered statistically significant.

\section{Results}

\subsection{Effects of magnesium on $\left[{ }^{3} \mathrm{H}\right]$ thymidine incorporation in VSMCS}

Magnesium did not influence $\left[{ }^{3} \mathrm{H}\right]$ thymidine incorporation under basal condition. The addition of PDGF to VSMCs caused a significant increase in $\left[{ }^{3} \mathrm{H}\right]$ thymidine incorporation. However, under this stimulated condition, magnesium did not affect $\left[{ }^{3} \mathrm{H}\right]$ thymidine incorporation (data not shown). These observations indicated that magnesium did not influence the DNA synthesis of VSMCs.

\subsection{Effects of magnesium on the production of $M M P-2$ in $V S M C s$}

Gelatin zymograms of VSMC-conditioned media showed that the major MMP expressed under these conditions was MMP-2. Magnesium reduced the production of MMP-2 significantly in a dose-dependent manner (Fig. 1A).

MMP-2 protein was shown to be expressed by western blotting of culture medium, probed using an anti-MMP-2 antibody. Magnesium induced a significant
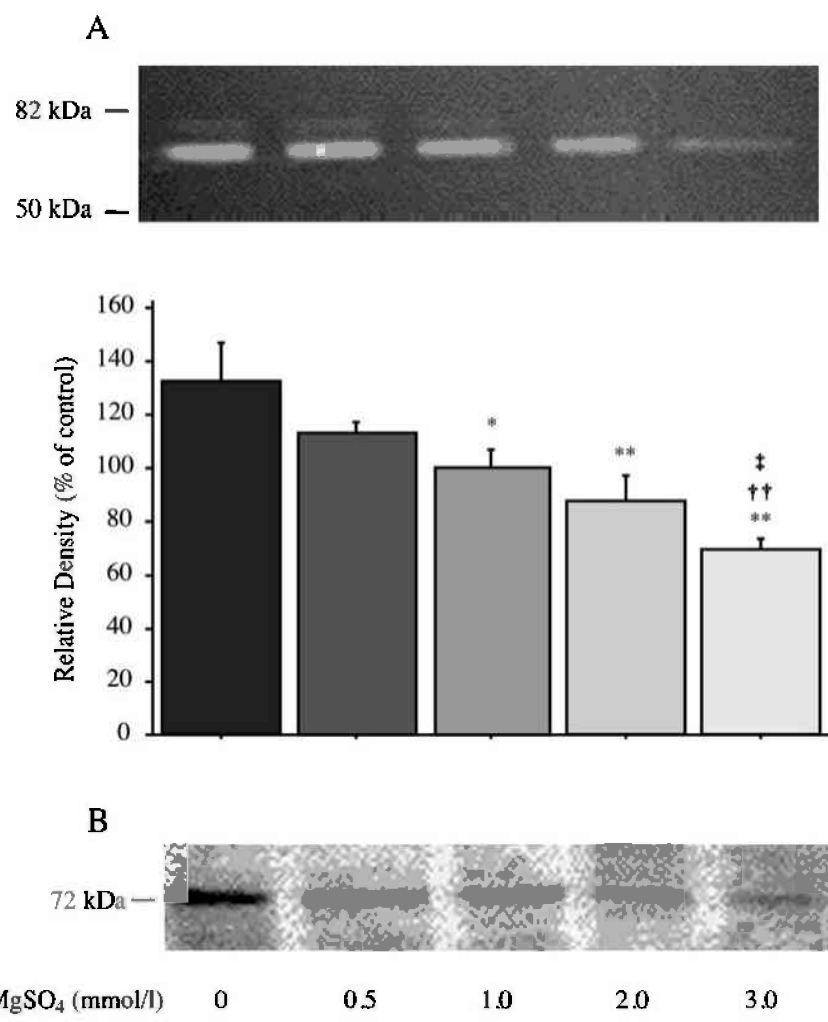

Fig. 1. Effects of magnesium on production of MMP-2 in cultured vascular smooth muscle cells. $\mathrm{MgSO}_{4}$ significantly reduced the production of MMP-2 as determined by zymography (A) and western blotting (B) in a dose-dependent manner. Clear zones against the blue background indicated the presence of MMP-2. Columns indicate data of gelatinolytic activity as percentages of the amount of control (1.0 $\mathrm{mmol} / \mathrm{l} \mathrm{MgSO}_{4}$ ), and represent the mean \pm S.E. for four separate experiments performed in duplicate. ${ }^{*}, P<0.05$ vs. $\mathrm{MgSO}_{4} 0 \mathrm{mmol} / \mathrm{l}$; **, $P<0.01$ vs. $\mathrm{MgSO}_{4} 0 \mathrm{mmol} / \mathrm{l} ; \dagger, P<0.01$ vs. $\mathrm{MgSO}_{4} 0.5 \mathrm{mmol} / \mathrm{l}$; t. $P<0.05$ vs. $\mathrm{MgSO}_{4} 1.0 \mathrm{mmol} / \mathrm{l}$.

and dose-dependent reduction in MMP-2 production (Fig. 1B).

\subsection{Effects of magnesium on production of $M M P-2$ stimulated by PDGF in VSMCS}

As PDGF is known to be secreted by vascular cells and to regulate MMP-2 synthesis in VSMCs, we next examined the effects of magnesium on cells stimulated with PDGF. Magnesium decreased the MMP-2 production significantly under these conditions in a dosedependent manner (Fig. 2A). MMP-2 protein was shown to be expressed by western blotting of culture medium probed using anti-MMP-2 antibody. Magnesium induced a significant and dose-dependent reduction of MMP-2 production by cells stimulated with PDGF (Fig. 2B). These effects were not toxic as determined by trypan blue exclusion. 

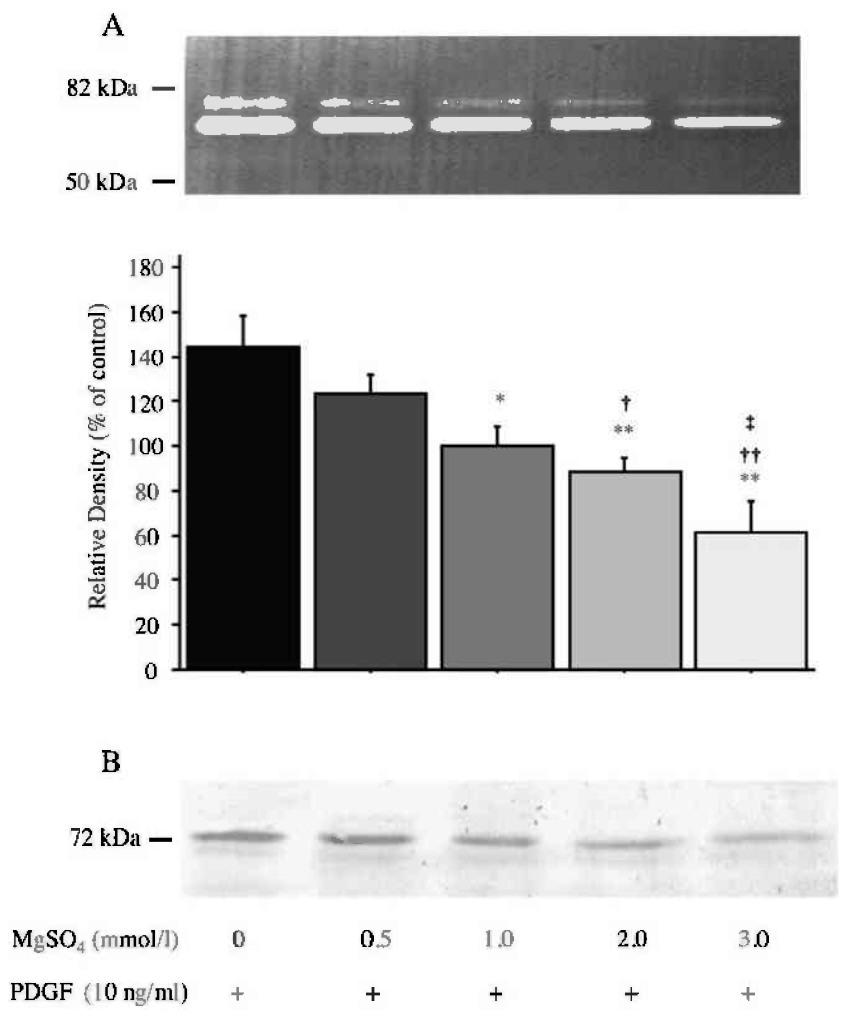

Fig. 2. Effects of magnesium on production of MMP-2 stimulated by PDGF in cultured vascular smooth muscle cells. $\mathrm{MgSO}_{4}$ significantly and dose-dependently decreased the production of MMP-2 as determined by zymography (A) and western blotting (B) under conditions of stimulation by PDGF. Clear zones against the blue background indicate the presence of MMP-2. Columns are as described in Fig. 1. Treatment with $1.0 \mathrm{mmol} / 1 \mathrm{MgSO}_{4}$ together with PDGF was regarded as control. *, $P<0.05$ vs. $\mathrm{MgSO}_{4} 0 \mathrm{mmol} / \mathrm{l} ;$ **, $P<0.01$ vs. $\mathrm{MgSO}_{4} 0$ $\mathrm{mmol} / \mathrm{l} ; \dagger, P<0.05$ vs. $\mathrm{MgSO}_{4} 0.5 \mathrm{mmol} / \mathrm{l} ; \dagger+, P<0.01$ vs. $\mathrm{MgSO}_{4} 0.5$ $\mathrm{mmol} / \mathrm{l} ; \stackrel{\dagger}{\dagger} P<0.05$ vs. $\mathrm{MgSO}_{4} 1.0 \mathrm{mmol} / \mathrm{l}$.

\subsection{Effects of anions and ions on production of MMPs}

To verify that the altered MMP production by $\mathrm{MgSO}_{4}$ was due to magnesium ions and not a nonspecific effect of sulfate anions, the effects of magnesium chloride on the production of MMP-2 were compared with those of $\mathrm{MgSO}_{4}$. No significant differences were seen in the degree of decrease in MMP-2 production between $\mathrm{MgSO}_{4}$ and magnesium chloride (data not shown), indicating that the effect on MMP-2 production was due to neither sulfate nor chloride anions but to magnesium ions. To examine whether other divalent cations, such as zinc and copper, have any effects on MMP-2 production, VSMCs were treated with zinc sulfate or copper sulfate culture medium, which were made in the same way as the $\mathrm{MgSO}_{4}$ treatments, to the final concentrations of $0-100 \mu \mathrm{mol} / 1$ for $24 \mathrm{~h}$. No influences were found in MMP-2 production by VSMCs treated with either zinc sulfate or copper sulfate (data not shown), indicating that the effect of magnesium on MMP-2 production in VSMCs was specific but not a common character of divalent cations.

\subsection{Effects of magnesium on the zymography system}

To detect the effects of magnesium on the zymography system, subconfluent VSMCs were treated with 0 $\mathrm{mmol} / \mathrm{l}$ magnesium for $24 \mathrm{~h}$, then the $0 \mathrm{mmol} / \mathrm{l}$ culture medium was adjusted to different magnesium concentrations $(0-3.0 \mathrm{mmol} / \mathrm{l})$ before zymography. Magnesium did not influence MMP detection under these conditions. The lack of an inhibitory effect of magnesium on MMP expression after removal of cells demonstrated the feasibility of studying the effects of magnesium on MMP detection by the zymography system (data not shown).

\subsection{Effects of protein tyrosine kinase inhibitors on magnesium-induced MMP-2 production}

To evaluate whether the effects of magnesium on production of MMP-2 were related to protein tyrosine kinase, subconfluent VSMCs were treated with two protein tyrosine kinase inhibitors, genistein and herbimycin $\mathrm{A}$ for $10 \mathrm{~min}$ before treatment with magnesium in culture media at concentrations $0-3.0 \mathrm{mmol} / 1$. A pretreatment with either genistein $(10 \mu \mathrm{mol} / \mathrm{l})$ or herbimycin A $(0.5 \mu \mathrm{g} / \mathrm{ml})$ with magnesium resulted in an inhibition of the alterations on MMP-2 production induced by magnesium (Fig. 3A and B).

\subsection{Effects of calcium channel blockers on the production of MMP-2 in VSMCs under basal and PDGF-stimulated conditions}

As magnesium is called a natural calcium antagonist, we compared the effects of magnesium with those of calcium antagonists, verapamil and nifedipine, under basal and PDGF-stimulated conditions. Neither of the calcium antagonists affected the $\left[{ }^{3} \mathrm{H}\right]$ thymidine incorporation under either the basal or PDGF-stimulated conditions in VSMCs (data not shown). Verapamil and nifedipine had no influence on the production of MMP2 under basal or PDGF-stimulated conditions at any concentrations tested $\left(10^{-8}-10^{-6} \mathrm{~mol} / \mathrm{l}\right.$; Fig. 4).

\section{Discussion}

The major finding of this study was that extracellular magnesium supplementation reduced the production of MMP-2 under basal and PDGF-stimulated conditions in rat VSMCs. To our knowledge, this is the first report of the effects of magnesium on the production of MMP2 in cultured rat VSMCs, and these effects appears to be associated with the protein tyrosine kinase pathway. Clinically, Shibata et al. [18] reported that intravenous administration of magnesium decreased serum levels of 

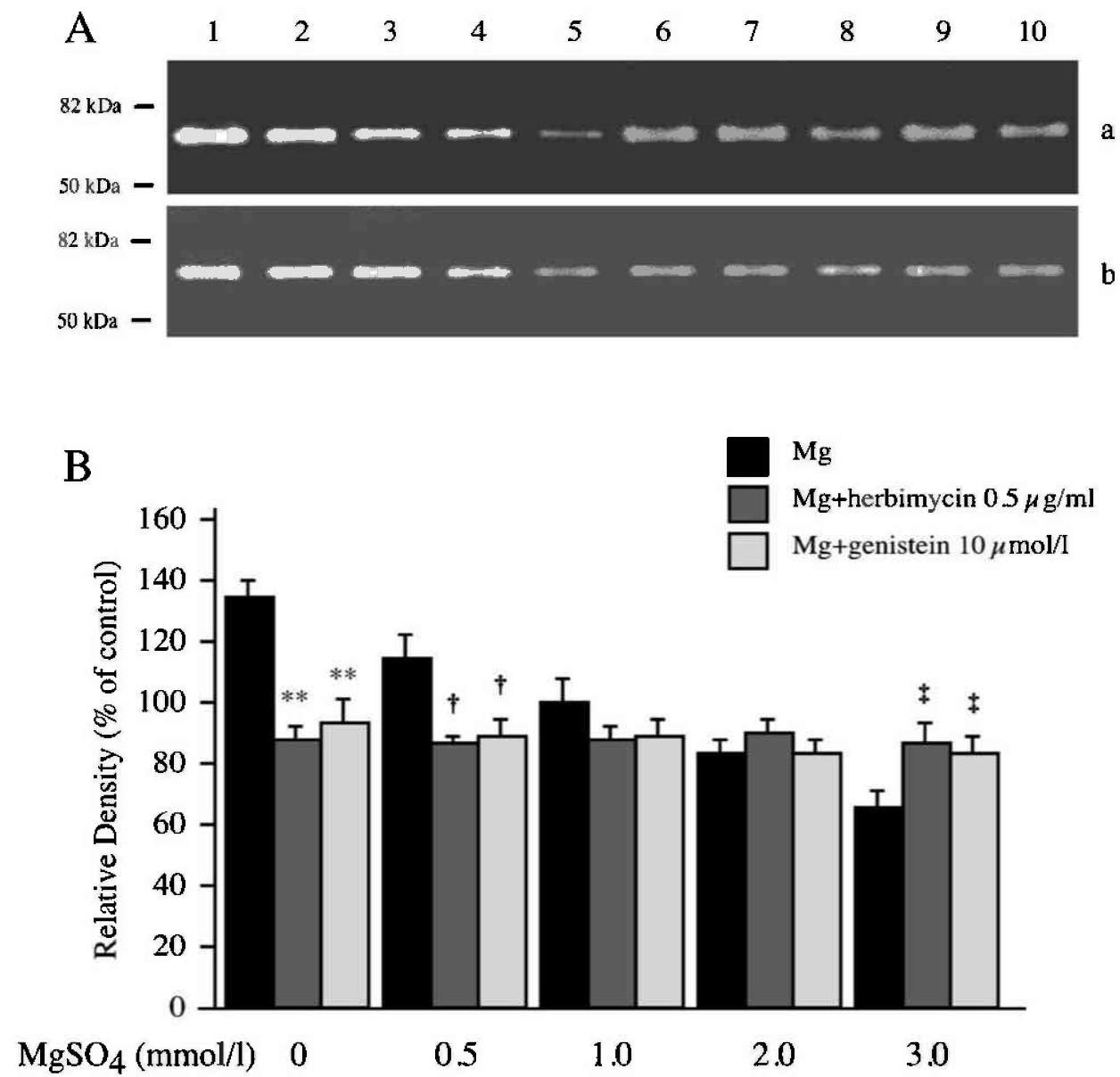

Fig. 3. Effects of protein tyrosine kinase inhibitors on magnesium-induced MMP-2 production in cultured vascular smooth muscle cells. $\mathrm{MgSO}_{4}$ induced alterations of MMP-2 production (at concentrations of $0,0.5$ and $3.0 \mathrm{mmol} / \mathrm{l}$ ) were significantly inhibited by two protein tyrosine kinase inhibitors, genistein and herbimycin A. Clear zones against the blue background indicate the presence of MMP-2. Lane $1-5$ represent $\mathrm{MgSO}_{4}$ groups with concentrations of $0-3.0 \mathrm{mmol} / 1$, lane 6-10 represent combined treatment groups of herbimycin A (a) and genistein (b) with $\mathrm{MgSO}_{4} \mathrm{Of}_{0-3.0}$ $\mathrm{mmol} / \mathrm{l}$, separately shown by zymography (A). The statistical data are shown in B. Columns are as described in Fig. $1 .{ }^{* *}, P<0.01$ vs. $\mathrm{MgSO}_{4} 0$ $\mathrm{mmol} / \mathrm{l} ; \uparrow, P<0.05$ vs. $\mathrm{MgSO}_{4} 0.5 \mathrm{mmol} / \mathrm{l} ;$ : $P<0.05$ vs. $\mathrm{MgSO}_{4} 3.0 \mathrm{mmol} / \mathrm{l}$.

MMP-1 in patients with acute myocardial infarction, which supports our investigation.

It is clear that MMPs are important in any process in which matrix turnover and repair take place. The roles of MMPs in the processes of atherosclerosis are mainly related to VSMCs migration and proliferation, resulting in the formation of a plaque, and a weakening of plaque caps before fissuring [8]. MMPs are known to be expressed in human atherosclerotic plaques by both SMCs and macrophages in vivo $[19,20]$. The major MMP expressed in vitro in VSMCs has been shown to be MMP-2 [21], which is consistent with the present study.

Magnesium, a natural calcium antagonist, can act on potential-operated channels, receptor-operated channels, and leak-operated channels in the cardiovascular system [22]. Recently, magnesium has been shown to inhibit capacitative $\mathrm{Ca}^{2+}$ entry in VSMCs [23]. Using CAI (carboxy amino-triazole), a receptor-operated calcium influx inhibitor, Kohn et al. found a marked reduction in MMP-2 activity and suggested a role for calcium-mediated signal transduction in the expression of metalloproteinases [12]. In our study, two potentialoperated calcium channel blockers, nifedipine and verapamil, had no influence on MMP-2 production while magnesium reduced MMP-2 production. Therefore, it's possible that magnesium affected MMP-2 production in VSMCs through a calcium-mediated signal transduction pathway like CAI.

Protein phosphorylation on tyrosine residues by protein tyrosine kinases is an important regulator of cell function [24]. Li et al. [25] and our laboratory [9] have demonstrated that MMP-2 production or activation was induced through protein tyrosine phosphorylation. Recently, protein tyrosine phosphorylation has been shown to play important roles in $\mathrm{Mg}^{2+}$ deficiencyinduced contraction of isolated rat smooth muscle [26]. Furthermore, activation of several cellular signaling pathways, such as protein tyrosine kinases and mitogen-activated protein kinase, appears to play important 


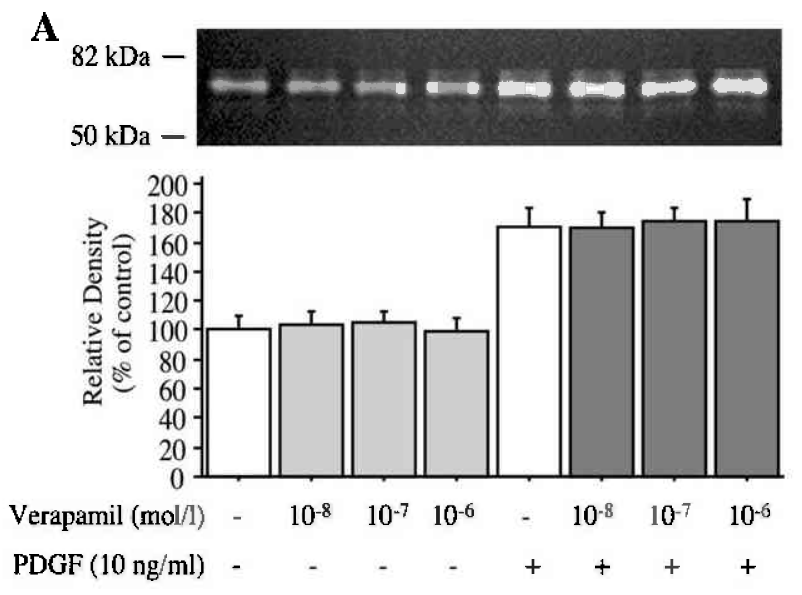

B
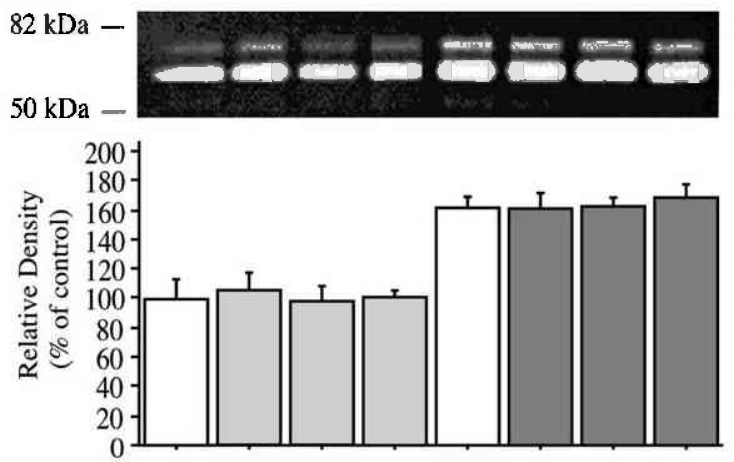

Nifedipine (mol/l) - $10^{-8} \quad 10^{-7} 10^{-6} \quad-\quad 10^{-8} \quad 10^{-7} \quad 10^{-6}$

PDGF $(10 \mathrm{ng} / \mathrm{ml})$ - $\quad-\quad+\quad++++$

Fig. 4. Effects of verapamil and nifedipine on the production of MMP-2 under basal and PDGF-stimulated conditions in cultured vascular smooth muscle cells. Neither verapamil nor nifedipine influenced the production of MMP-2 under either basal or PDGFstimulated conditions. Clear zones against the blue background indicate the presence of MMP-2. Columns are as described in Fig. 1.

roles in low $\left[\mathrm{Mg}^{2+}\right]_{0}$-induced contraction and the elevation of $\left[\mathrm{Ca}^{2+}\right]_{i}$ in smooth muscle cells from canine basilar arteries [27]. Therefore, it is likely that there is a close relationship among magnesium, MMP-2 and protein tyrosine phosphorylation. In the present study, we observed that in agreement with above studies, a hypomagnesium (magnesium concentrations of $0.5-0$ mmol/l)-induced increase in MMP-2 production was blocked by either genistein or herbimycin A. We further observed that a hypermagnesium (magnesium concentrations of $3.0 \mathrm{mmol} / \mathrm{l}$ )-induced decrease in MMP-2 production was also inhibited by either genistein or herbimycin A. Therefore, our data suggest that the effects of magnesium on production of MMP-2 in VSMCs might be related, at least in part, to a protein tyrosine kinase pathway.

\section{Conclusions}

In cultured rat VSMCs, magnesium significantly reduced the production of MMP-2 under basal and PDGF-stimulated conditions in a dose-dependent manner, while neither verapamil nor nifedipine showed any effect under the same conditions. The effects of magnesium on MMP-2 production were inhibited by both genistein and herbimycin $\mathrm{A}$. Our data suggest that the beneficial effect of magnesium supplementation on vascular disease processes may be due, at least in part, to the inhibitory effect of magnesium on the production of MMP-2 in VSMCs, which appears to be associated with a protein tyrosine kinase pathway.

\section{Acknowledgements}

This study was supported in part by a Grant-in-Aid for General Scientific Research (No. 08770492, No. 12770339) from the Ministry of Education, Science and Culture of Japan. We are also grateful to Miss Hiromi Nishimura for her technical assistance.

\section{References}

[1] Comstock GW. Water hardness and cardiovascular diseases. Am J Epidemiol 1979;110:375-400.

[2] Altura BT, Brust M, Bloom S, Barbour RL, Stempak JG, Altura BM. Magnesium dietary intake modulates blood lipid levels and atherogenesis. Proc Natl Acad Sci USA 1990;87:1840-4.

[3] Satake K, Lee JD, Shimizu H, Ueda T, Nakamura T. Relation between severity of magnesium deficiency and frequency of anginal attacks in men with variant angina. J Am Coll Cardiol 1996;28:897-902.

[4] Liao F, Folsom AR, Brancati FL. Is low magnesium concentration a risk factor for coronary heart disease? The Atherosclerosis Risk in Communities (ARIC) Study. Am Heart J 1998;136:48090.

[5] Liotta LA, Steeg PA, Stetler-Stevenson WG. Cancer metastasis and angiogenesis: an imbalance of positive and negative regulation. Cell 1991;64:327-36.

[6] Zempo N, Koyama N, Kenagy RD, Lea HJ, Clowes AW. Regulation of vascular smooth muscle cell migration and proliferation in vitro and in injured rat arteries by a synthetic matrix metalloproteinase inhibitor. Arterioscler Thromb Vasc Biol 1996;16:28-33.

[7] Ross R. The pathogenesis of atherosclerosis: a perspective for the 1990s. Nature 1993;362:801-9.

[8] Dollery CM, McEwan JR, Henney AM. Matrix metalloproteinases and cardiovascular disease. Circ Res 1995;77:863-8.

[9] Uzui H, Lee J-D, Shimizu H, Tsutani H, Ueda T. The role of protein-tyrosine phosphorylation and gelatinase production in the migration and proliferation of smooth muscle cells. Atherosclerosis 2000;149:51-9.

[10] Foda HD, George S, Rollo E, et al. Regulation of gelatinases in human airway smooth muscle cells: mechanism of progelatinase $\mathrm{A}$ activation. Am J Physiol 1999;277:L174-82. 
[11] Li Z, Li L, Zielke R, et al. Increased expression of 72-kd type IV collagenase (MMP-2) in human aortic atherosclerotic lesions. Am J Pathol 1996;148:121-8.

[12] Kohn EC, Jacobs W, Kim YS, Alessando R, Stetler-Stevenson WG, Loitta LA. Calcium influx modulates expression of matrix metalloproteinase-2 (72-KDa type IV collagenase, gelatinase A). J Biol Chem 1994;269:21505-11.

[13] Iseri LT, French JH. Magnesium: nature's physiologic calcium blocker. Am Heart J 1984;108:188-94.

[14] Tsukada T, Tippens D, Gordon D, Ross R, Gown AM. HHF35, a muscle-actin- specific monoclonal antibody. I. Immunocytochemical and biochemical characterization. Am J Pathol 1987;126:51-60.

[15] Blair EI, Kim IC, Estes JE, Keski-Oja J, Schomberg DW. Human platelet- derived growth factor preparations contain a separate activity which potentiates follicle-stimulating hormone-mediated induction of luteinizing hormone recepter in cultured rat granuloma cells: evidence for transforming growth factor-beta. Endocrinology 1988;123:2003-8.

[16] Tyagi SC, Meyer L, Schmaltz RA, Reddy HK, Voelker DJ. Proteinases and restenosis in the human coronary artery: extracellular matrix production exceeds the expression of proteolytic activity. Atherosclerosis 1995;116:43-57.

[17] Pickering JG, Ford CM, Tang B, Chew LH. Coordinated effects of fibroblast growth factor-2 on expression of fibrillar collagens, matrix metalloproteinases, and tissue inhibitors of matrix metalloproteinases by human vascular smooth muscle cells. Evidence for repressed collagen production and activated degradative capacity. Arterioscler Thromb Vasc Biol 1997;17:475-82.

[18] Shibata M, Ueshima K, Harada M, et al. Effect of magnesium sulfate pretreatment and significance of matrix metalloproteinases- 1 and interleukin- 6 levels in coronary reperfusion therapy for patients with acute myocardial infarction. Angiology 1999;50:573-82.
[19] Henny AM, Wakeley PR, Davies MJ, Foster K, Hembry R, Murphy G, Humphries SE. Localization of stromelysin gene expression in atherosclerotic plaques by in situ hybridization. Proc Natl Acad Sci USA 1991;88:8154-8.

[20] Galis ZS, Sukhova GK, Lark MW, Libby P. Increased expression of matrix metalloproteinases and matrix degrading activity in vulnerable regions of human atherosclerotic plaques. J Clin Invest 1994;94:2493-503.

[21] Pauly RR, Passaniti A, Bilato C, et al. Migration of cultured vascular smooth muscle cells through a basement membrane barrier requires type IV collagenase activity and is inhibited by cellular differentiation. Circ Res 1994;75:41-54.

[22] Altura BM, Altura BT, Carella A, Gebrewold A, Murakawa T, Nishio A. $\mathrm{Mg}^{2+}-\mathrm{Ca}^{2+}$ interaction in contractility of vascular smooth muscle: $\mathrm{Mg}^{2+}$ versus organic calcium channel blockers on myogenic tone and agonist-induced responsiveness of blood vessels. Can J Physiol Pharmacol 1987;65:729-45.

[23] Yoshimura M, Oshima T, Matsuura H, Ishida T, Kambe M, Kajiyama G. Extracellular $\mathrm{Mg}^{2+}$ inhibits capacitative $\mathrm{Ca}^{2+}$ entry in vascular smooth muscle cells. Circulation 1997;95:2567-72.

[24] Hunter T. Protein kinases and phosphatases: the yin and yang of protein phosphorylation and signaling. Cell 1995;80:225-36.

[25] Li L, Eisen AZ, Sturman E, Selter JL. Protein tyrosine phosphorylation in signaling pathways leading to the activation of gelatinase A: activation of gelatinase A by treatment with the protein tyrosine phosphatase inhibitor sodium orthovanadate. Biochim Biophys Acta 1998;1405:110-20.

[26] Yang Z-W, Altura BT, Altura BM. Low extracellular $\mathrm{Mg}^{2+}$ contraction of arterial muscle: role of protein kinase $\mathrm{C}$ and protein tyrosine phosphorylation. Eur J Pharmacol 1999;378:273-81.

[27] Yang Z-W, Wang J, Zheng T, Altura BT, Altura BM. Low $\left[\mathrm{Mg}^{2+}\right]_{\mathrm{o}}$ induces contraction of cerebral arteries: roles of tyrosine and mitogen-activated protein kinases. Am J Physiol Heart Circ Physiol 2000;279:H185-94. 